Journal of Jazz Studies vol. 10, no. 1 pp. 78-90 (Summer 2014)

\title{
"You've got to appreciate all kinds of music"
}

\author{
Ricky Riccardi
}

Louis Armstrong: Master of Modernism. By Thomas Brothers. New York: W.W. Norton \& Company. 608 pp.

What they say about the old days is corny. They form their own opinions, they got so many words for things and make everything soooo big-and it turns out awhat you call it-a fictitious story.

Louis Armstrong to Richard Meryman, summer $1965 .{ }^{1}$

Louis Armstrong's life was so rich it seems to inspire at least one major new book each year. Some have been straight-ahead biographies, but others have focused on Armstrong's offstage talents (designing collages or writing autobiographical manuscripts) or specific times in his life (the Hot Fives and Sevens period or his All Stars years). Some books are better than others but each one is compelling. With a life like Louis Armstrong's it's almost impossible to write a bad book about him. Thomas Brothers's Louis Armstrong: Master of Modernism does not qualify as a bad book but because of the author's flawed agenda and false conclusions, it makes for a very disappointing read.

This is Brothers's third book on the trumpeter, after the essential anthology, Louis Armstrong In His Own Words, ${ }^{2}$ and 2006's Louis Armstrong's New Orleans, an important work that explored the background of Armstrong's 1954 autobiography, Satchmo: My Life in New Orleans. With Louis Armstrong: Master of Modernism, Brothers takes the story into the 1920s and early 30s, the years where Armstrong revolutionized the sound of American popular music with both his horn and his voice. Much has already been written about these years, but Brothers is the first to get nearly 600-pages to really detail Armstrong's life and innovations in this crucial era. However, even at its length, it feels both incomplete and, at the same time, inflated.

Even with its flaws, Brothers has done a heroic amount of research and provides enough fresh insights to recommend this book to any hardcore

\footnotetext{
${ }^{1}$ Richard Meryman, Louis Armstrong: A Self-Portrait (New York: Eakins Press, 1971), 55.

${ }^{2}$ New York: Oxford, 1999.
} 
Armstrong fan. For example, when writers tackle Louis Armstrong's life in the 1920s, they usually focus on the Hot Five and Seven recordings and not much else. By focusing on recorded masterpieces such as "Cornet Chop Suey" and "West End Blues," a distorted picture of Armstrong the "serious artist" was produced, something many writers clung to when confronted with Armstrong's gregarious, onstage "Satchmo" persona of his later years. Brothers treats the Hot Fives and Sevens with all the respect they deserve, but he's smart enough to know that those sessions barely made up a dozen different days over a three year stretch of Armstrong's life. What mattered most to the trumpeter was what he did on a nightly basis and Brothers makes those nights positively come alive. He pieces together what a day at the Vendome Theater was comprised of and takes his readers through an exhilarating evening of music, comedy, and dancing at such Chicago cabarets as the Sunset Café. Even later on, when Armstrong came to New York in 1929, Brothers gives a detailed account of the African-American theater scene during that era, putting Armstrong's arrival into its proper context.

When it comes to Armstrong's music, Brothers rightly emphasizes Armstrong's methods of working on his improvised solos and gradually "setting" them when satisfied with them. Armstrong's 1920s recordings are still sometimes analyzed as masterpieces of pure improvisation, but in recent years, that line of thinking has been questioned. Now, Brothers' descriptions of Armstrong's solo-creating habits are clear as day and hopefully, future generations of historians will benefit.

There are fascinating details into all the different meanings of the word "jazz" during the period, as well as how groups such as the African-American "Talented Tenth" disapproved of it. Brothers's analysis of how OKeh Records split Armstrong's recordings between its "race" and "popular" series' is equally illuminating. And there's refreshing praise for Armstrong's 1929-1932 "pop song" output for OKeh. These recordings usually get unfairly overshadowed by the Hot Fives and Sevens but they're tremendously important, as Armstrong more or less solidifies "The Great American Songbook" with his inventive versions of songs such as "Star Dust," "Body and Soul" and "I Surrender Dear." Armstrong's trumpet playing and singing were in peak form in these years, something Brothers rightly emphasizes (it was very pleasing to see attention given to "Indian Cradle Song," a 1930 recording that rarely gets reissued). There's plenty of new information gleaned from the pages of AfricanAmerican newspapers and periodicals that will surprise those who have read every book there is to find on Armstrong (who knew that the phrase "Heah Me Talkin' to Ya" was the catchphrase of a comedian, Marshall "Garbage" Rogers?). And one cannot argue with one of Brothers's central points: that 
Armstrong should be thought of "not only as a great jazz musician and a great entertainer but as one of the great melodists in American music."

All of these insights make Master of Modernism an important work, but it's some of Brothers's other tendencies that ultimately make it a disappointment. Brothers inserts quotes from seemingly every musician who was alive in those years, but he sometimes selectively chooses those that support his own preconceived theories, quotes that do not line up with what Armstrong believed. Armstrong took great pains to make sure his opinions were documented, as he liked to say, "for posterity," on a series of over 700 reel-toreel tapes that have been available to researchers at the Louis Armstrong House Museum [full disclosure: I have been Archivist there since 2009] for over a decade. While Brothers does quote from seven of them, he tends to ignore or downplay the trumpeter's own words. In the end, there's too much Brothers and too little Armstrong.

Brothers frequently dismisses Armstrong's avowed love of opera and classical music, even though Armstrong talked about buying opera records in New Orleans, records he continued to listen to until his final days (his original 78s still exist at the Louis Armstrong House Museum). Brothers writes that "too much is made out of Armstrong's only documented connection to opera in New Orleans" before arguing that to emphasize opera "is to willfully ignore what was an extensive and thorough immersion in the early preferences of a rich and strong array of African-American vernacular traditions." The question is, why does it have to be one or the other? Armstrong was clearly immersed in African-American traditions and became a master at playing the blues, but he still enjoyed those opera records and listened to them-and dubbed them to tape-for decades to come. Brothers argues that the only reason Armstrong talked about listening to opera and different kinds of music was because appearing "open-minded...suited the cultural position he occupied so well in the segregated America of the 1950s."

This attitude is completely at odds with Armstrong's own words. In February 1965, Armstrong engaged in a tape-recorded conversation with members of the "New Orleans Jazz Club" at the Peabody Hotel in Memphis. The entire time, the New Orleans members just wanted to talk about traditional jazz and blues but Armstrong implores them to expand their minds. After praising the Beatles, Armstrong says, "You see, now we got to be not to partial to one kind of music. You've got to appreciate all kinds of music. That's what I'm trying to put in your head. Listen to all kinds of music. I got classics ... Some of your best jazz musicians came from symphonies. And some of your best riffs." At this point, Armstrong burst into a scatted version of a melody from Rigoletto. "That comes from opera! Yeah! 'Sextet from Lucia.' All 
right then. That's your best riffs. And you've got to give more credit to them." Brothers would not agree with such a statement, taking it to the point of ignoring Armstrong's more operatic recordings such as 1925's "Pickin' On Your Baby" and 1930's "Dear Old Southland." Writing about Armstrong's 1929 recording of "Ain't Misbehavin'," Brothers mentions Armstrong's quote of "Rhapsody in Blue," saying, "This is Armstrong's first documented musical quotation." But this completely omits Armstrong's quoting of Franz Drdla's light classical number, "Souvenir," in his backing on Clara Smith's "Court House Blues" in 1925, as well as his quoting of Rigoletto during a break on Johnny Dodds's 1927 recording of "New Orleans Stomp." By ignoring the earlier quotes of Rigoletto and "Souvenir," Brothers is either demonstrating that he didn't do enough listening or he didn't want to give further credence to a classical influence on Armstrong's playing.

When Brothers does discuss Armstrong's New Orleans upbringing, he primarily focuses on the blues and the importance of the blues to AfricanAmericans in that period. That's all true, but focusing solely on the blues paints an incomplete picture of Armstrong's musical background, as well as his tastes. Writing in one of his manuscripts about the famed Funky Butt Hall, Armstrong said, "The Funky Butt gave me quite a bit of my ear for music and inspiration. They would play Ragtime, Fox trots, Waltzes, Tangos, Mazookas, Schottische in fact all kind of tempos which helped me through the years to play with different orchestras, symphany [sic], show music, etc." ${ }^{3}$ Clearly, Armstrong heard a lot of music in New Orleans and played a lot of different music, too, whether singing "Shine on Harvest Moon" with his vocal quartet, playing "Put on Your Old Grey Bonnet" at the Colored Waifs Home or playing popular songs like "In the Land of Beginning Again" with Fate Marable's riverboat band. Of Marable's band, Armstrong told George Avakian during a taped conversation in 1953, "Oh, we played all kinds of music. We had to play waltzes and rhumbas, fox trots, you know, cause [we played for] all types of people." Later in life, Armstrong began talking about the experience of singing Russian lullabies with the Jewish Karnofsky family in New Orleans. They encouraged Armstrong to sing lullabies "from the heart," but, as Armstrong related in 1970, "But when I went to the other side to one of them honky-tonks, you know, and tried to sing [like that], and them cats gambling, 'Man, don't you come in here with all that noise!' You know what I mean? They didn't encourage me at all." ${ }^{4}$ Armstrong was already showing an affinity

\footnotetext{
${ }^{3}$ Louis Armstrong, "The Armstrong Synopsis," unpublished manuscript held at the Louis Armstrong House Museum, c. 1950, 3.

${ }^{4}$ Louis Armstrong, The David Frost Show, June 9, 1970.
} 
for pretty melodies, but he had to stick to the blues in his neighborhood because that's what they wanted to hear. But even during the Hot Fives sessions, Armstrong was once asked to record a blues and, according to Johnny St. Cyr, he first demurred because "they all sound alike." There can be no denying that Armstrong was a phenomenal blues player and that the blues did play a big role in his New Orleans career, but to focus solely on that is to disrespect Armstrong's big ears and all the other music he was experiencing and performing during that same period.

This includes the music of both black and white musicians. Armstrong always gave credit to white trumpeters Vic D'Ippolito and B.A. Rolfe, each of whom get small mentions in Master of Modernism. Brothers knocks the New Orleans Rhythm Kings, quoting Mezz Mezzrow on how they "stole Joe Oliver's riffs and they stole them good" (p. 63). But he never mentions Armstrong paying tribute to their clarinetist, Leon Roppolo, on one of his private tapes in 1952, calling Roppolo "a great clarinetist who played with the New Orleans Rhythm Kings in 1922 and 1923 in Chicago" and adding, "I had the pleasure of rehearsing with them every time they made a record for the Gennett company." Brothers does allow Armstrong to get in some words of praise for Bix Beiderbecke, but then he writes off Beiderbecke by mentioning "shadowy sexual deviance, including pederasty and masochism" (p. 282). Nowhere does Brothers mention that the charges for Beiderbecke's 1921 arrest for a "lewd and lascivious act with child" were completely dismissed. It's a careless, slanderous way to write off a historic figure and friend of Armstrong's.

Brothers' main agenda is to focus on Armstrong's immersion in the black vernacular, and this leads to other important white entertainers of the time being relegated to the sidelines. Brothers doesn't mention that Armstrong seems to be channeling $\mathrm{Al}$ Jolson on some of his early Hot Fives vocals, especially "Big Butter and Egg Man." On a private tape from 1964, Armstrong said to a friend, "How do you like Al Jolson's work? Wasn't he something? Goddamn, I love him! Al Jolson, Bill Robinson and Bing [Crosby]... There's something about Jolson, boy." Could Jolson have had some effect on Armstrong? It's probable, but Brothers doesn't mention it. Crosby, too, is only mentioned in passing a handful of times-once simply lumped in with other white crooners of the day-giving no hint that Armstrong might have picked up on some of Crosby's habits.

There's also the conspicuous absence of Armstrong's future manager, Joe Glaser, who ran the Sunset Café. Brothers assumes Armstrong was embarrassed by Glaser billing him at the Sunset as the "World's Greatest Trumpeter," , but Armstrong frequently told the story about how Glaser stood up to one of Al Capone's henchmen who wanted him to take down the sign. 
Armstrong remembered Glaser saying, "I think that Louis Armstrong is the world's greatest and this is my place and I defy anybody to take his name down from there. ${ }^{\prime 5}$ Armstrong repeated that story often through the years, but Glaser is only mentioned once in connection with the Sunset. OKeh executive Elmer "E. A." Fearn is shockingly not mentioned at all. As Gene H. Anderson has written in his book on the Hot Fives, without Fearn, "... [T] the celebrated [OKeh] recordings would never have been made." ${ }^{\prime}$ Armstrong talked about Fearn frequently over the years, most explicitly regarding his role in the success of "Heebie Jeebies." Armstrong told Avakian, "They just didn't want to waste all the masters and [Fearn] thought it was a good idea, and it was his ideaand that's his idea and it turned out all right. Cause before that, records had to be perfect, you know. And he said, 'Hell, we're going to take a chance on this one." Armstrong also gave Fearn credit for coining the word "scat," relating on another tape, "Scat' wasn't even mentioned until after that recording was made and Mr. Fearn, the president of the Okeh Recording Company said, 'Louie Armstrong, this is where scat was born.' I say, 'Yeah? Okay. Thank you, Mr. Fearn."

While covering the Hot Fives, Brothers repeatedly asserts that these recordings were aimed at Southern, African-American audiences. This is mostly true since the songs were issued as "race records," but again, Brothers goes one step too far and asserts on page 220, "It is likely that very few whites outside the Sunset Café heard his scat breakthroughs, or even heard of him at all during these productive years in Chicago." But Brothers doesn't mention the September 1926 issue of the Italian Supplemento Fonotipia-Odeon, featuring a photograph of Armstrong on the cover with the headline, "Le Ultime Novita" ("The Latest Novelty"). This artifact was sent to Fearn along with a letter from Allan W. Fritzock, the Vice President in Charge of Sales for Odeon, dated September 3, 1926. "We would suggest your giving these to Louis, showing him the tremendous amount of publicity he is securing by means of his Okeh contract, so that any time he sees fit to go to Italy, they will welcome him with open arms," Fritzock wrote to Fearn. The letter and catalog were sent to Armstrong by Fearn and glued onto the pages of one of his scrapbooks, a scrapbook Brothers consulted and quotes from frequently. By his omitting any reference to these documents and to Fearn, Brothers ignores the fact that

\footnotetext{
${ }^{5}$ Louis Armstrong, letter to Oscar Cohen, January 21/23, 1970, reproduced in Jazz auction catalog (Guernsey's, 2005), 14-17

${ }^{6}$ Gene Henry Andersen, The Original Hot Five Recordings of Louis Armstrong (Hilldale, NY: Pendragon Press, 2007), 7.
} 
Armstrong had achieved worldwide recognition almost from the start of his career.

Armstrong made no secret of his kinship with white musicians during the 1920s: rehearsing with the New Orleans Rhythm Kings, inviting Muggsy Spanier to play at the Sunset, jamming after hours with Beiderbecke, and eventually recording the masterpiece "Knockin' a Jug" in 1929 with an integrated group. He spent much of his life talking about, "It's no crime for cats of any color to get together and blow," and demonstrated that with his actions. But Brothers argues that these statements have been overblown, writing, "It is no surprise that his attitudes toward whites, during this and other periods, are very hard to uncover. A lot of his commentary on this period comes from the 1950s, a time when he assumed the identity of Ambassador Satch and when he occasionally liked to articulate visions of universal brotherhood" (p. 306). Thus, Brothers chooses to devalue Armstrong's words and, instead, quotes contemporaries such as Scoville Brown, Garvin Bushell ("As a matter of fact, we had no desire to integrate then" [p. 306]) and columnist Dave Peyton, who wrote about how Armstrong "slaughtered all of the ofay jazz demons" at the Savoy Ballroom (p. 291). Brothers runs with that quote, repeating it often and arguing that that's what Armstrong's cadenza to "West End Blues" was created to do. This is all well and good for Brown and Bushell and Peyton, and I'm sure there were many other black musicians who felt the same way as they did, and with good reason. But one would expect that in a book about Louis Armstrong, Armstrong's own words would do the talking, especially since his attitudes towards whites are far from hard to uncover.

When it comes to describing the actual music, Brothers occasionally relies too heavily on jargon, repeating phrases like "fixed and variable" so many times, it loses its meaning after a while. "Fixed and variable" is a concept introduced by Olly Wilson to describe the two rhythmic groups common in the music of Africa. Brothers defines it as "one instrument (or group of instruments) plays a repeated rhythmic figure. This 'fixed' level orients the listener or dancer, while the 'variable' instrument or group brings the music to life by departing from the repeated figure in interesting ways" (p. 6). A variable instrument playing over a fixed rhythm? To Brothers and Wilson, this is an African-centric concept, and no one would deny that it is a valid characteristic of the music of that region of the world. But to this writer, it sounds like it could be used to describe a lot of different music, not just music of Africa. It's a shaky way to

\footnotetext{
${ }^{7}$ Max Jones, John Chilton and Leonard Feather, Salute to Satchmo (London: IPC Specialist and Professional Press , 1970), 99.
} 
give Armstrong a sense of African retention, which is one of Brothers' big goals, but Brothers repeats it so often, it sounds like he's trying to convince himself. Early on in the book, Brothers defines the word "riff," making it appear as a book for the layman, but later, some of his musicological descriptions are so dense, one wonders who he had in mind as his target audience.

As mentioned earlier, most of Brothers' conclusions about Armstrong's music and innovations are spot on, but, overall, his strengths seem to lie in issues of race and culture. Though he's undoubtedly a fine musicologist, Brothers's analyses of some of Armstrong's specific recordings illustrate that he is far from a jazz specialist. In each of his first two books about Armstrong Brothers did not have to deal with any recorded music. But in this one, he has to deal with some of the most frequently analyzed works of $20^{\text {th }}$ century art, and this causes him to falter repeatedly.

For example, Brothers repeats the assertion that Armstrong struggled with plunger mutes, but then praises his playing on "Everybody Loves My Baby" without ever mentioning that it's a plunger-muted solo! And an excellent one at that, which proved that Armstrong could do it, but because he loved the pure tone of the trumpet so much, he didn't like messing with it (decades later, Ruby Braff remembered Armstrong complaining to him that Harry "Sweets" Edison had a beautiful open horn tone but used a mute too frequently). He wrongly assumes Armstrong's solo on "Beau Koo Jack" to be written out, and really misjudges Jimmie Rodgers's "Blue Yodel Number 9" as "heavily laden with racist ideologies" (p. 381) without mentioning that Rodgers's lyrics pay tribute to "The Bridwell Blues," recorded by the African-American singer Nolan Welsh in 1926 with Armstrong backing him up on cornet. To Brothers, pianist Lil Armstrong "undoubtedly" is using a lead sheet on "Blue Yodel," which again, is wrong. Rodgers was from the "I'll-change-chords-when-I-feellike-it" school, something Armstrong touched upon in a 1953 radio interview with Irwin Johnson, saying, "And we never did end up on the bar, you know, so I had to get with him. I just made it wrong with him! It turned out fine." That kind of playing cannot be notated.

And in perhaps the most egregious error in the whole book, Brothers analyzes the cornet solo on Fletcher Henderson's "Alone at Last" as being by Joe Smith instead of Armstrong. This solo has been discussed as a great Armstrong outing for decades, but Brothers seems to be ignorant of that fact. How he could mistake Armstrong's signature sound, time, and feel (one phrase even seems to preview "Struttin' with Some Barbecue") for Smith's is unfathomable. One would hope that by his third book, Brothers would be able 
to recognize Armstrong's completely identifiable sound, but that is apparently not the case.

Still, even with the errors, wrongheaded observations and calculated omissions, Brothers always treats Armstrong with respect. This is not a meanspirited book, such as James Lincoln Collier's, where Collier bemoaned Armstrong as an artist who "failed his own talent." Brothers clearly admires Armstrong and applauds his innovations and skill at navigating a minefield of race-related obstacles. All of this, though, makes the ending of Master of Modernism so upsetting, with Armstrong ending up as a fallen hero, someone who could not triumph over white expectations, a tragic figure who had to live the rest of his life tortured by his choices.

Brothers telegraphs the ending of his book by titling chapter 8, "The White Turn," the word "turn" being used as when a character in a story "turns" on the hero or "turns" from good to evil. Brothers repeatedly claims that Armstrong's ambition was "to reach the largest white audience possible" (p. 401). Armstrong's true ambition was to reach the largest audience possible, black and white, American and international, and he achieved it. He did start losing African-American fans in the early 1950s, but to Brothers it happened much earlier, starting with Armstrong's 1929 recording of "I Can't Give You Anything But Love," which Brothers calls "a farewell song of appreciation to his adoring African-American fan base in Chicago" (p. 331).

Brothers actually has some of his finest moments after this "farewell song" hypothesis; his discussions on the African-American theater scene, on Armstrong's drug use, on his "ragging" the popular tunes of the day, and his exceptional offerings at more moderate tempos during the early 1930s are on the mark. He even settles down regarding his use of jargon and seemingly antiwhite generalizations (Guy Lombardo shows up and emerges unscathed). It seemed like Brothers was heading towards ending on a strong note, ready to leave Armstrong on the doorstep of conquering Europe and eventually, the world.

But instead, Brothers grows more and more despondent as Armstrong apparently pushes his black audience aside to chase the white fans (and money), most of whom are painted as racists. Brothers begins chronicling Armstrong's fall, first bemoaning his recording numbers like "Just a Gigolo" (where Armstrong sings "just another jig I know" instead of the title phrase) and "Shine," and then for adopting "When It's Sleepy Time Down South" as his theme song. Brothers argues that Armstrong "was hitting the big time on all cylinders and satisfying expectations, even if they disgusted him" (p. 440).

${ }^{8}$ Louis Armstrong: An American Genius (New York: Oxford, 1983). 
Regarding "Sleepy Time," Brothers writes it off as just a plantation song and gives Armstrong's "gift for acting" credit because "you are convinced that Armstrong ... identifies with the song completely."

To Brothers, that's an impossible notion. So why did Armstrong continue performing "Sleepy Time" until the day he died? "It is almost as if the modern master had to sing Sleepy Time, and it is easy to understand why," Brothers writes before unleashing perhaps the most jaw-dropping sentence in the entire book. "If he was going to advance further on the ladder of his career-and he definitely was - he had to assure white audiences on a deep level that he had no designs on social progress." (p. 441) Armstrong publicly bragged about putting it in his contract that he wouldn't play any hotels he couldn't stay at, and when he started his All Stars in 1947, insisted to Joe Glaser that it remain integrated, even if it meant staying out of New Orleans for a decade. "Ain't nobody gonna call me intolerant," he told the press in $1956 .{ }^{9}$ Does that sound like a man with no designs on social progress?

Brothers then turns to the movies for the concluding passages of his book. $\mathrm{He}$ finds no saving grace or transcending moments in Armstrong's performances in Rhapsody in Black and Blue and the Betty Boop cartoon, I'll Be Glad When You're Dead Rascal You; by this point, Armstrong "had met his match" (p. 446). Brothers offers a list of the demeaning roles Armstrong would continue to play in films of the 1930s and concludes, "Rather than search desperately for subtle signs of subversion, it is more honest to simply acknowledge how he was damaged by one of the sweeping ideological battles of the twentieth century" (p. 448). He then lumps Armstrong in with other artists who "suffered such a fate," naming Dmitri Shostakovich (who had "a tortured life") and Richard Strauss (who "suffered the consequences in international condemnation"). The end comes a few pages later, Armstrong a one-time genius who ended up loser in the battle against racism.

(In perhaps the most comic of Brother's errors, he claims that white audiences viewed Armstrong in the same way as they saw the "southern mammy" on the Aunt Jemima pancake box, quoting an Ed Sullivan "joke" from 1935: "Louis Armstrong and Aunt Jemima go into the Park Avenue Hotel." Brothers writes, "He didn't have to say anything more." He didn't have to; readers at the time would have realized that Sullivan wasn't making a joke, he was simply letting his readers know that Armstrong would be performing with Tess Gardella, the Italian-born woman who performed for years in

\footnotetext{
${ }^{9}$ Eddy Gilmore, "Happy Ambassador for U.S. That's Our Satchmo Abroad," Hartford Courant, May 27, 1956, 16E.
} 
blackface as "Aunt Jemima." Sullivan had no jokes or pancake boxes on his mind.)

If you have never read another book about Armstrong, it's easy to believe what Brothers is selling. Armstrong's life was inexorably tied up with issues of race, and some of those films do offer images of the jazz's greatest genius that are uncomfortable to modern audiences. But Brothers counts Armstrong out in 1932, setting the stage for what he refers to as "the last, impure decades of his career." But really, instead of the "international condemnation" suffered by Strauss, Armstrong was on the brink of full-blown international superstardom, about to become beloved by audiences around the world, just as he continues to be beloved by those same audiences today. African-Americans did not abandon him for making those early films. Joe Glaser took over Armstrong's career in 1935, and as Armstrong recounted in 1965, "[It was years before] Joe Glaser realized I could play with white boys. He didn't know. And play for white people! When I first signed up with him, he just booked me in colored dances." ${ }^{10}$ Armstrong remained proud of his film work and the exposure it gave him. Even after those first two demeaning films, he listed his occupation as "Actor and Musician" on his 1932 passport, and by the 1940s and beyond, he conquered the screen repeatedly, usually as himself or roles based on himself in films with Dorothy Dandridge, Danny Kaye, Jimmy Stewart, Bing Crosby, Paul Newman, Sidney Poitier, Sammy Davis Jr., and others.

But throughout the depressing final chapter, one voice is silenced: Louis Armstrong's own. As Brothers draws conclusion after conclusion on pieces like "Shine" and "Sleepy Time Down South," he never consults Armstrong's own words. Brothers imagines Armstrong tolerating the "disgusting side effects" of "Sleepy Time" and can't fathom Armstrong actually identifying with it. One of Armstrong's most famous quotes is, "You don't pose, never, that's the last thing you do, because the minute you pose, you're through as a jazzman. Jazz is only what you are." ${ }^{11}$ Armstrong was 100\% real every time he stepped on stage and audiences understood that. Every time Armstrong was asked to name his favorite song, he answered, "Sleepy Time Down South." The reason wasn't to alert white audiences about his aversion to progress. He didn't think of plantations either; he was from the south and the song meant something to him on a personal level. "Yeah, it is, because I, being from the South, I know the life, and the words live," he said during a 1952 interview on one of his tapes. "You know, cats in the sunshine, they lazy, layin' up against the tree and

${ }^{10}$ The Show of the Week, BBC television broadcast filmed on June 3, 1965 and aired on October 16, 1965. Accessed on CD at Louis Armstrong House Museum, 1987.3.345.

${ }^{11}$ Jones, Chilton and Feather, Salute to Satchmo, 63. 
all that stuff there. That's all in that song and it's facts. And the music is pretty." Armstrong was also proud that the song was written for him by three African-American writers and liked to open with it because "the warmth is there." For these reasons, and probably more, Armstrong never apologized for "Sleepy Time."

Even regarding "Shine," Armstrong did not back down. In 1956, Armstrong was asked to be a guest disc jockey for the Voice of America. For five hours, he would tell stories and spin records of his own choosing, including "Shine." Armstrong was aware of the controversy around the number, but for the Voice of America, he wanted to set the record straight. "Now pertaining to titles and things, I remember the time we made a record called 'Shine,' 'Black and Blue,' things like that, why people would-you know, especially our people, the Negroes-they'd probably get insulted a little for no reason at all," he said, adding, "It's nothing but music and kicks." As soon as the record ended, Armstrong got back on the microphone and shouted, "There you go! See, now what's wrong with 'Shine'? I mean, the people are so narrowminded, they're worrying about the title, they forgot to listen to all that good music!...And I think if we just take it in a little easier stride, I don't know-a lot of people worry about a whole lot of unnecessary things and they don't do nothing about it." Armstrong continued doing something about it (the Voice of America program was a year before his Little Rock stance) for the rest of his life. "I don't sigh for nothing," he said in 1965, and he meant it. ${ }^{12}$ Less than a year before he died, Armstrong set the record straight on how he felt about a number of subjects in a series of letters to British writer Max Jones. He ended one by saying, "Well, folks, that was my life and I enjoyed all of it. Yes I did. I don't feel ashamed at all. My life has always been an open book so I have nothing to hide."

That's the voice of Louis Armstrong. No bitterness. No resentment. No self-pitying. He was completely open and willing to share his feelings on every subject imaginable. With more quotes and observations from Armstrong himself, Master of Modernism could have been one of the most important books ever written about the trumpeter. Instead, the editor of Louis Armstrong In His Own Words has produced Louis Armstrong In Thomas Brothers' Words. Though there are many worthwhile moments in its nearly 600 pages, Brothers's theories and conclusions are so at odds with those of Armstrong's, in the end, it turns out, as Armstrong would have described it, "a-what you call it-a fictitious story."

${ }^{12}$ Meryman, Louis Armstrong: A Self-Portrait, 57. 


\section{About the Contributor}

RICKY RICCARDI is the Archivist for the Louis Armstrong House Museum and author of What a Wonderful World: The Magic of Louis Armstrong's Later Years. He runs the online blog, "The Wonderful World of Louis Armstrong," at dippermouth.blogspot.com and has given lectures on Armstrong at venues around the world, including the Institute of Jazz Studies, the Satchmo Summerfest and the Monterey Jazz Festival. He has recently co-produced Satchmo at Symphony Hall 65th Anniversary: The Complete Concert for Universal Music and Columbia and RCA Victor Live Recordings of Louis Armstrong and the All Stars for Mosaic Records. He is also a jazz pianist based out of Toms River, NJ and received his Master's in Jazz History and Research from Rutgers University.

The Journal of Jazz Studies (JJS) is published by the Institute of Jazz Studies at the Newark campus of Rutgers, The State University of New Jersey. JJS is hosted online by the Rutgers University Libraries at http://jjs.libraries.rutgers.edu. 